\title{
Business Process Improvement Using Service Blueprint Method on Sharia Account Opening PT Bank Syariah XYZ
}

\author{
Nurhidayati ${ }^{1}$, Mohammad Hamsal ${ }^{2}$ \\ \{ibobanad@gmail.com ${ }^{1}$, sdm2000@mail.com²\} \\ University of Indonesia ${ }^{1}$, Management Department ${ }^{2}$, BINUS Business School Doctor of Research of \\ Management ${ }^{3}$, Bina Nusantara University ${ }^{4}$, Jakarta, Indonesia 11480
}

\begin{abstract}
This paper describes how the Service Blueprint method can be used to improve the business process of Sharia account opening in PT Bank Syariah XYZ. In this era of connectivity and digitalization, customers do not want to be faced with the complicated process, including a process in account opening. By using the Service Blueprint method, we can sort out which activities provide non-value added, identify potential service failures and risk of excessive wait. This paper proposes a new service design that can eliminate non-valued added activities, reduce the number of service failures and reduce cycle time, so it can increase productivity and customer satisfaction. By using qualitative and quantitative research methods through indepth interview with Bank Officials and survey to 403 repondents, it can be known which activities are bottlenecks and potentially lead to service failure. Based on this, the authors propose a new service design using digitalization with regard to customer preferences in opening accounts. Beside reducing time delivery in opening account, this new design also has an impact on cost reduction.
\end{abstract}

Keywords: Business Process Improvement, Service, Service Blueprint, Service Design, Value-Added, Fail Point, Excessive Wait, Redesign.

\section{Introduction}

Internet 4.0 era raises a new phenomenon towards changes in consumer behavior. The digital revolution is one of the most significant influences on consumer behavior [1]. Today's consumers create consumer space by dictating companies with products and services that can be accessed anytime, anywhere and through any devices. The products and services have changed from product-centric to customer-centric. Consumers also have high buying power and become very demanding. They want services that are fast, easy, simple and inexpensive, including in financial services.

Indonesian consumers have unique characteristics that are different from other countries. Although globalization and digitalization influence the values, behavior, and aspirations of Indonesian consumers, local Islamic values remain dominant influencing their mindset, attitude and patterns of action. This is a natural thing because $87.13 \%$ of Indonesia's population is Muslim [2]. Most of the Indonesian Muslim population is in the middle class. The growth of 
middle class Muslims has created a new phenomenon by moving the Muslim market in Indonesia. One thing that interesting about this phenomenon is that Islamic values become a driving factor for Indonesian Muslim consumers in deciding purchases and influencing their buying and consumption behavior. However, segmentation of these communities when viewed from the indicators of preference and ownership of financial products is still based on things that are ego-centric and rational. They prioritize the functional side and the benefits of the banking products/services itself, rather than the emotional side. In this era of digitalization and connectivity, customers do not want to be faced with a complicated process. They want a simple way to open an account.

Based on MRI (2018), opening a Sharia savings account at Bank Syariah XYZ spent 36 minutes 14 seconds, while time to open a savings account in the banking industry was 25 minutes [3]. Thus, the delivery time to open a savings account in Bank Syariah XYZ is still longer than the industry's delivery time. Bank Syariah XYZ needs to improve business process in the process of opening a savings account so that it becomes more effective and efficient. According to that, the research in this paper has the objectives to identify account opening activities, review business process existing for opening a Sharia savings account (current state), propose a new business process for opening a Sharia savings account (future state), and identify gap analysis between business process current state and business process future state.

This paper presents the Service Blueprint method as a powerful tool for understanding, documenting, analyzing, and improving the service process. The Service Blueprint method can be one of the simplest ways to analyse problems visually as well as to detail other parts of a process or an entire process. It enhances the process of customer's encounter, identifies bottlenecks, unnecessary deeds, delays and duplications, assists in eliminating non-value added protocols, and reduces the intricacy of the process. It's very helpful for detailing business processes and getting a clear understanding of how and why the process works as it should.

The paper proceeds as follows. In section 2, literature review related to this research is explored. Then, the methodology is presented in section 3. Data and result is studied in section 4 . The final section 5 concludes the paper.

\section{Literature Review}

[3] Propose a Business Process Improvement (BPI) framework as a tool to trigger an appropriate response to market changes and / or customer needs that develop very dynamically [4]. This framework also serves as a guide to fixing the main problems and inefficiencies faced in today's business environment. The framework is divided into 3 (three) stages, namely: 1. Specify

This stage provides the basis for planning and implementing BPI. At this stage an analysis of the company's internal and external business environment is carried out.

2. Analyze

Analysis must be carried out to evaluate the potential impact of each feasible alternative BPI, and choose the BPI alternative that produces a significant impact on a broad scope of the entire organization (scope-wise and time-wise). This means ensuring that the chosen BPI approach will produce positive results that affect the entire organization, and expand not only in the short term, but also maintained in the long term.

3. Monitor 
The monitoring phase is a test of whether the desired goals and planned results have been realized. Monitoring must be carried out continuously. This requires full attention and includes detailed follow-up of all aspects needed to ensure effective implementation and control. The monitoring phase is influenced by various factors in each execution step, including problems related to labor, financial aspects, and intangible drivers of business performance, such as organizational culture, behavioral norms, and work climate.

The BPI framework stages can be illustrated as follows:

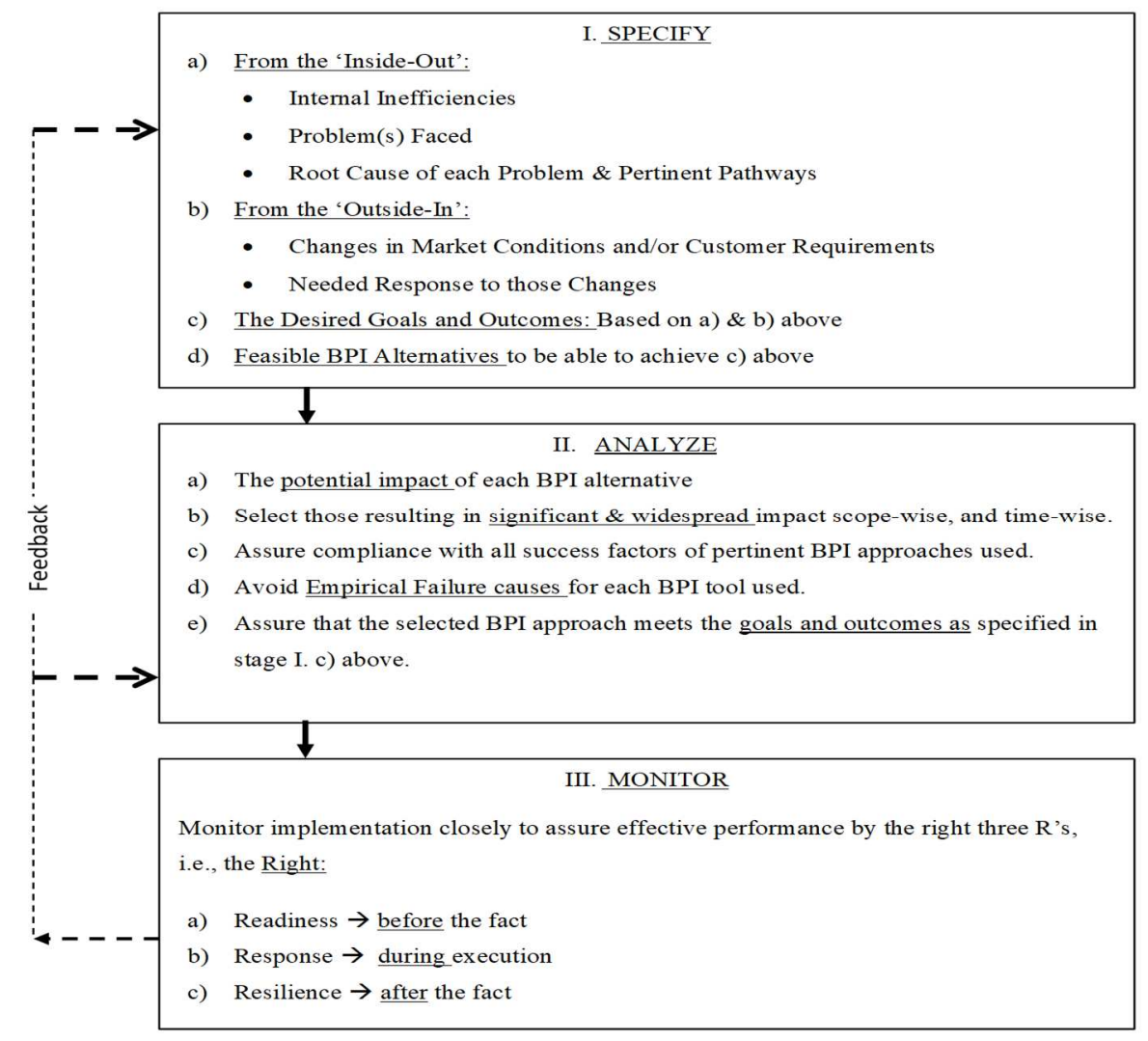

Figure. 1. Framework Business Process Improvement

When we talk about service, then we talk about an experience that viewed from a customer's perspective. Whereas from an organizational perspective, service is a process that must be designed and managed to process architecture in creating the desired customer experience [4] [5]. Service is a very important thing for a company because service can provide benefits for the company, service can provide loyal customers/team members/colleagues, and provide efficiency to the company. Service creates value for customers. Therefore, service is an attitude to survive and win competition in the future.

To design services that satisfy customers and are operationally efficient, marketers and operations specialists need to work together, and Service Blueprint can provide the same perspective and language for the various departments involved. Service Blueprint helps identify and reduce service failure points and provides important insights for redesigning the service process. 
[5] ilustrated Service Blueprint as follows [6]:

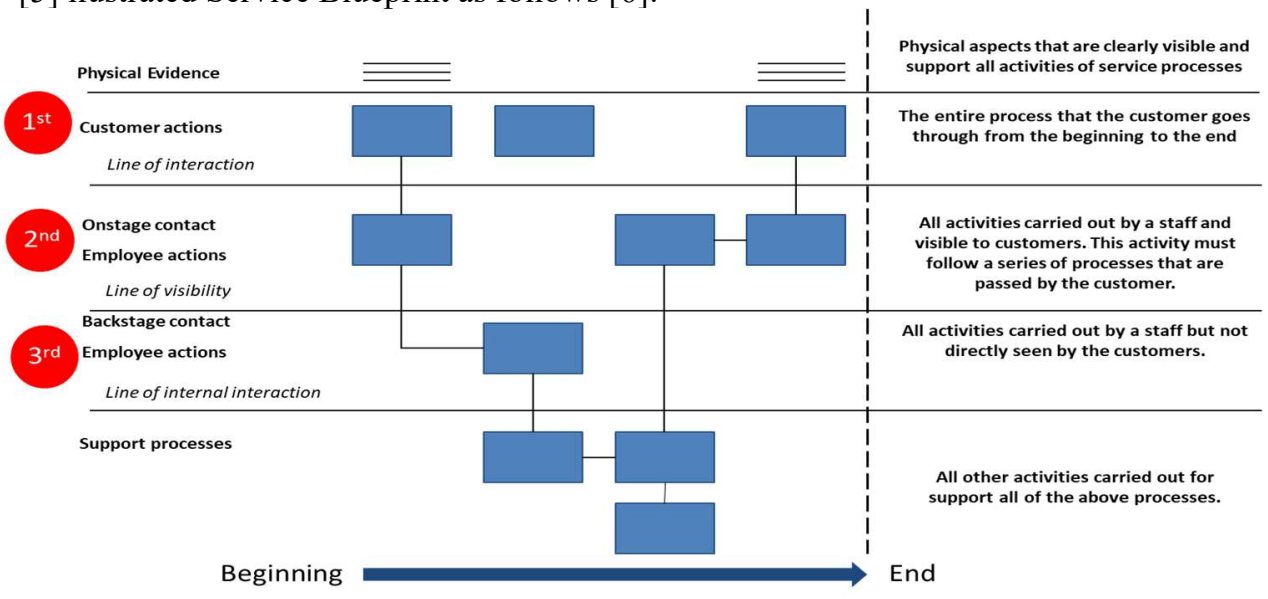

Figure. 2. Service Blueprint

In the era industrial 4.0, changes in technology, customer needs, new service offerings, and even applicable provisions make the existing service process inefficient or irrelevant. Changes in the external environment make the existing service processes obsolete, and thus, require redesign of the service process, or even create a new process so that the company remains relevant and responsive to customer needs. In addition, increasingly weak internal processes, increasing bureaucracy or lack of standardization of services, are considered in redesigning the service process or creating new processes that are more relevant to meet customer needs. [4] state that there are symptoms that indicate the service process when is not functioning properly and needs to be redesigned. These symptoms consist of requiring a lot of information exchange but the available data is useless; a high ratio of checking or control activities to value-adding activities; increased in the processing of exceptions; and growing numbers of customer complaints about inconvenient and unnecessary procedures [5].

Companies that will redesign service processes must look for opportunities to achieve a quantum leap in productivity and service quality at the same time. [4] stated that redesign efforts usually focus on achieving the following 4 (four) main objectives, and ideally, redesign efforts must reach all four of them simultaneously [5], namely: reducing the number of service failures; reducing the cycle time from customer initiation on service process until the completion of the process; increased productivity; and increase customer satisfaction.

\section{Methodology}

This research is intended to identify account opening activities, then review the current business process of opening a Sharia savings account (current state). Thus activities that do not provide non-value added, which have potential service failures (fail points), and have a risk of excessive wait during the process of opening a Sharia savings account can be identified. After that, it provides recommendations on the new business process for opening a Sharia savings account, which is more effective and efficient, so that time delivery for opening a Sharia savings account is the same as time delivery for opening a savings account in the banking industry. It is expected that the future state of business process can create a fast and modern service experience (value creation) to customers. 
This study uses 2 (two) approaches, namely quantitative and qualitative methods. Quantitative methods are used to answer the research hypothesis, while qualitative methods are used to define, analyze, and translate certain phenomena in depth [6]. The methodology in this research uses the framework as follows:

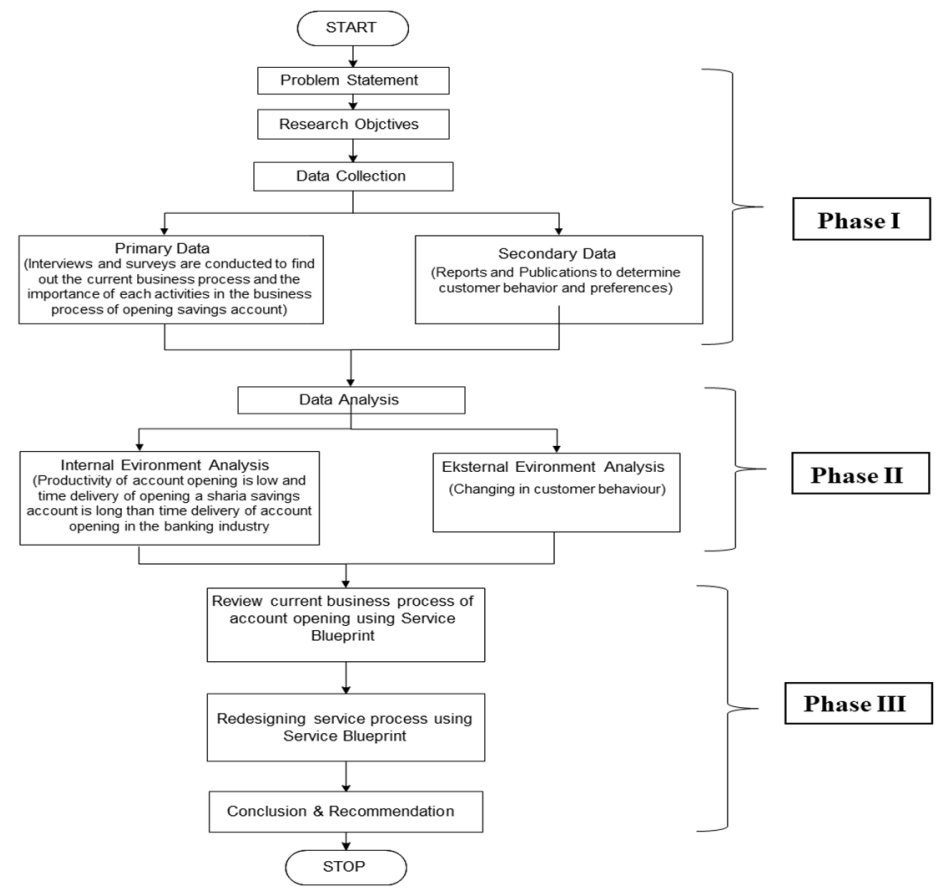

Figure. 3. Conceptual Framework

From the Figure 3 above, this research is divided into 3 (three) stages, namely:

- Phase I

At this stage, problems in the business process of opening a Sharia Savings account were identified through interviews. Interviews were conducted by in-depth interview with 7 (seven) Bank officers who became Subject Matter Experts (SMEs) involved in managerial and operational activites in opening Sharia savings account. The interview was conducted so that the author knew the fail points and bottlenecks that were felt from the side of the Bank and also the level of importance of each account opening activity. A questionnaire was also created and distributed to 403 customers of XYZ Syariah Bank to identify customer problems and preferences in the process of opening a Sharia savings account. The tendency of these customers to be identified through surveys is then used to analyze business activities in the account opening process based on value-added, non-value added, necessary but non-value added.

- Phase II

Data collected from interviews and surveys are used to analyze and map business process activities for opening savings account based on added value. From these data, it can be seen that account opening activities that are important for the Bank and the customer (value-added), 
important for the Bank (necessary but nonvalue-added), important for customers (necessary but nonvalue-added), not important for the Bank and customers (non-value added). Then from primary and secondary data can be used to analyze internal and external environmental conditions. From the analysis of the internal environment, it is known that the productivity of opening account at Bank Syariah XYZ is low and the time delivery of account opening is longer than the average time of opening an account in the banking industry. Whereas from the analysis of the external environment, it is known that there is a change in consumer behavior that affects consumer preferences in getting a product / service. The results of the analysis are used as the basis for preparing a business strategy by using the service blueprint method and formulating (or developing) new business processes that are in accordance with the needs and desires of the customer.

- Phase III

Analysis of the internal and external environment is then further translated into business strategies using the service blueprint. From the results of the service blueprint design, the new business process of opening Sharia savings account (future state) can be formulated to eliminate non-value added activities, minimize potential service failures and risk of excessive wait. In addition to providing a business process for opening Sharia savings account that is easier and faster, the proposed business process is expected to provide wow experience to the customers of Bank Syariah XYZ. So that the customers of Bank Syariah XYZ not only become loyal customers but become customers who can provide advocacy to prospective customers.

\section{Data and Result}

Based on the results of interviews with SMEs, there are 46 account opening activities in the business process of opening Sharia savings account. Out of the 46 account opening activities, the author mapped into 29 main activities in the current business process of opening accounts. Then author review the business process for opening the existing account.

Based on the level of importance, there are 22 activities that are important for the Bank and customers, 1 (one) activity is an unimportant activity for the Bank and the customer, namely waiting for the queue at the Teller for the initial deposit, and 6 (six) activities that are not important activities for the Bank but important for the customer, namely the arrival of the customer to the Branch, waiting for the account opening queue, asking the customer queue number, giving the passbook to the customer, assisting the customer in the Mobile Banking opening process on the customer's device and submitting the deposit slip to the customer to make an initial deposit to the Teller. From the level of importance of each account opening activity, a mapping is based on the value-added of each of these activities. The results of the mapping are as follows:

1. Value-added activities are 22 activities.

2. Non-value added activity is 1 (one) activity, namely: waiting for the queue at the Teller for the initial deposit.

3. Necessary but nonvalue-added activities are 6 (six) activities, namely: the arrival of the customer to the Branch, waiting for the account opening queue, asking the customer queue number, giving the passbook to the customer, assisting the customer in the Mobile Banking opening process on the customer's device and submitting the deposit slip to the 
customer to make an initial deposit to the Teller.

Of the 29 opening activities of Sharia Savings accounts, there are 17 activities that have potential fail points and 12 activities that have the potential risk of excessive wait. Based on the results of a review of the business process of opening the Sharia savings account, the authors propose redesigning an effective and efficient account opening business process by eliminating non-value added or waste and rework activities, and eliminating fail points activities and minimizing the risk of excessive wait. By transferring activities in the account opening process that can be carried out by the customer outside the business process of opening a Sharia Savings account at the Branch, making the business process of opening Sharia savings account faster. The activities such as filling out forms, collecting and inputting customer data, sharia education, product feature information, e-banking demos and activation of Mobile Banking can be done by customers themselves outside the business process of opening a Sharia savings account in the Branch. Including initial deposit activities that can be done via transfer or cash on Customer Service (CS), so customers do not need to move to the Teller to make an initial deposit. In addition, with the notification of queuing time, customers do not have to wait for the queue in the account opening process at the Branch. Customers can do other activities outside the Branch while waiting for their turn in the process of opening the Sharia Savings account. The proposed redesign of the business process of opening the Sharia savings account shortened service time from 38 minutes 52 seconds to 7 minutes 47 seconds. The proposed redesign of the business process for opening a Sharia Savings account can be seen as follow:

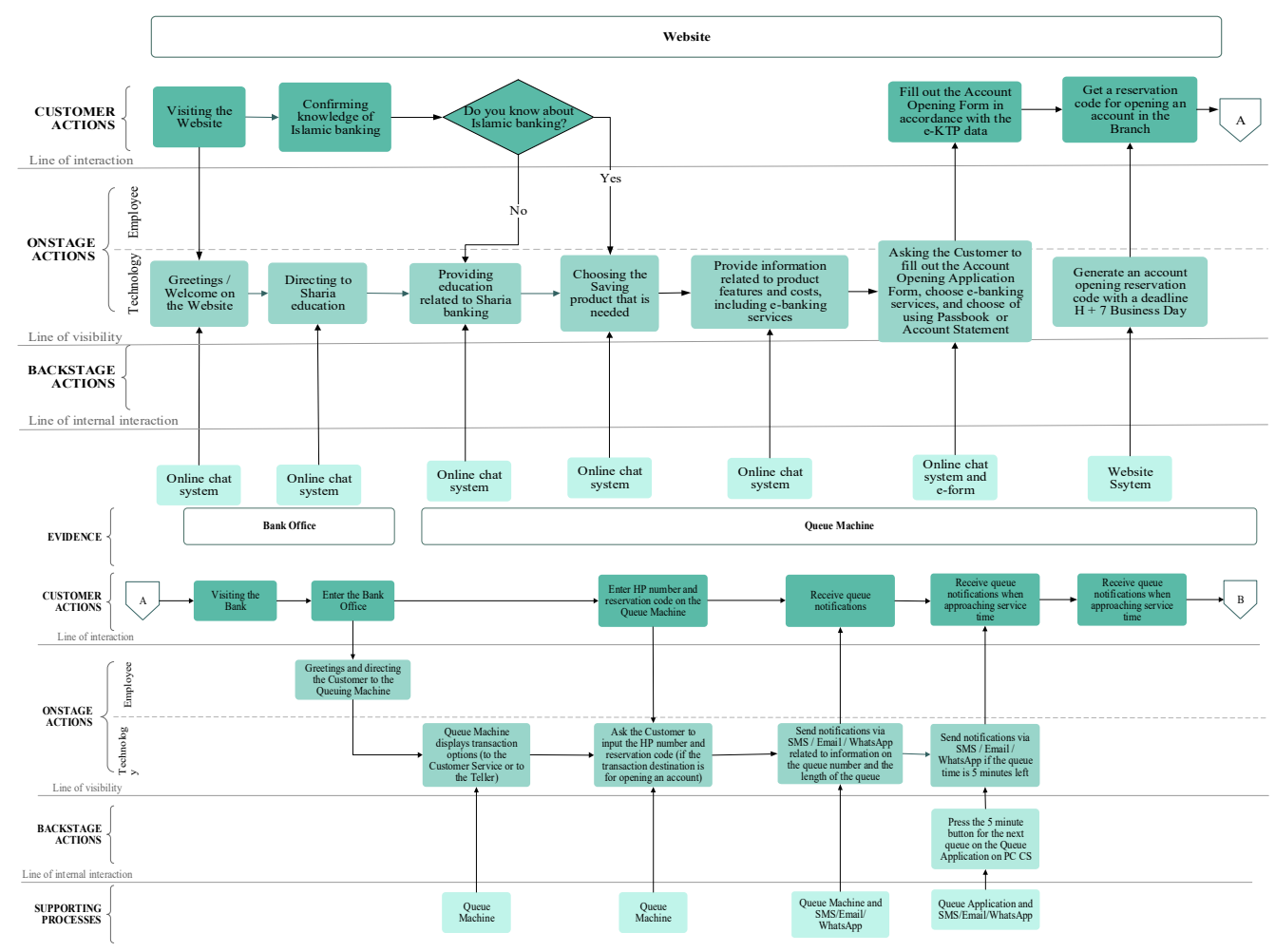




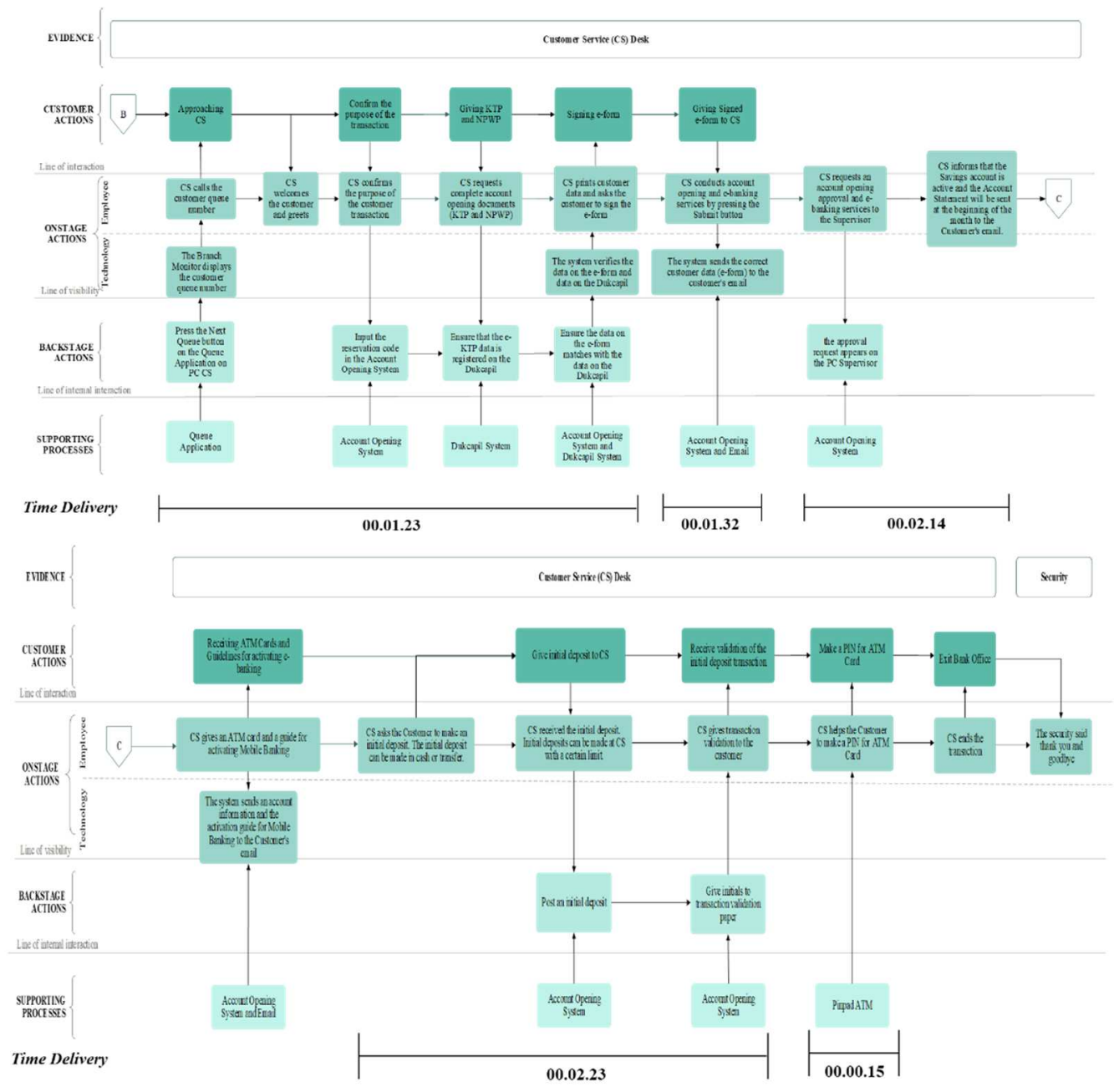

Figure. 4. Redesign Business Process of Opening Sharia Savings Account

\section{Conclusion and Recommendation}

\subsection{Conclusion}

By using the new business process of opening account (future state), the resulting differences are as follows:

1. The service time for opening a Sharia savings account is faster, which is 7 minutes 47 seconds.

2. Bank does not need to provide printed items, such as Account Opening Application Form and queue numbers, because they use e-forms (paperless), thereby reducing the cost of printing forms. 
3. Bank only uses one system for opening accounts and activating e-banking services, where the system is an in-house development, thereby reducing license fees for core banking usage.

4. CS and Teller become more comfortable in doing their work because they don't see long queues in the process of opening accounts and initial deposits.

5. A fast and convenient process, so it is expected that customers can easily and comfortably carry out the process of opening a Sharia savings account.

6. It is expected that branch productivity in opening accounts will increase.

\subsection{Management Implications}

With the new business process of opening a Sharia savings account, it will have an impact both tangible and intagible. The impacts given tangibly are as follows:

1. Changes to paper use for forms and queue numbers to be paperless.

2. Changes in a more seamless and comfortable Branch layout, making customers more comfortable in making transactions.

3. Changes from the use of 4 (four) systems in the business process of opening an account into 1 (one) system.

4. Cost reduction from printing account opening Form and core banking usage license fees.

While the impact given intangible is as follows:

1. Providing a sense of comfort in work because CS and Teller did not see a long queue.

2. Providing a sense of comfort to customers in making transactions because of the speed and convenience of the services provided.

\subsection{Recommendation}

The recommendation that can be given to Bank Syariah XYZ, Regulators and Academics are as follows:

1. Bank Syariah XYZ

a. Developing a new design for business process of opening accounts (future state) so that the opening of a Sharia savings account becomes more effective and efficient.

b. Reframing the beliefs of the image of Bank Syariah XYZ, so that the vision of being the Leading and Modern Islamic Bank is embedded in the minds of the people.

c. Monitoring the performance of the new business process design for opening account.

d. Disseminating and marketing communication to the public related to Islamic banking and sharia products so that people become more familiar with Islamic banking products.

e. Continuous improvement is related to the business process of opening Sharia savings accounts and banking transactions.

2. Regulators

a. Improve Islamic banking literacy and inclusion.

b. Conducting an introduction and socialization to the public regarding Islamic Banking and sharia products.

c. Providing incentives to Islamic Banks in carrying out literacy and inclusion regarding Islamic products to the public.

d. Supporting Islamic Banking in penetrating the market with incentives for provisions that make it easier for people to access Islamic Banking.

e. Synergize with the Ministry of Home Affairs to cleanse Electronic KTP data so that bank can easily access data and use the data as Customer Due Diligence (CDD) to 
customers.

3. Academics

a. Developing this research so that people can easily access and open accounts easily and quickly.

b. Conduct research to develop literacy and penetration of Islamic Banking to the public.

c. Develop research to understand the unique customer behavior of the Indonesian people who mostly are Muslims. 


\section{References}

[1] M. R. Solomon, Consumer Behavior: Buying, Having, Being. 2012.

[2] BPS, "Sensus Penduduk Tahun 2010," Sensus Pendud. 2010, 2018.

[3] S. M. Siha and G. H. Saad, "Business process improvement: Empirical assessment and extensions," Bus. Process Manag. J., 2008, doi: 10.1108/14637150810915973.

[4] C. Lovelock and J. Wirtz, Services Marketing: People, Technology, Strategy. 2011.

[5] V. A. Zeithaml, M. J. Bitner, and D. D. Gremler, "Services Marketing Strategy," in Wiley International Encyclopedia of Marketing, 2010.

[6] D. R. Cooper and P. S. Schindler, Business Research Methods 12th Edition. 2014. 